\begin{tabular}{c} 
Volume and Issues Obtainable at Center for Sustainability Research and Consultancy \\
Journal of Accounting and Finance in Emerging Economies \\
ISSN: 2519-0318 ISSN (E) 2518-8488 \\
Volume 3: Issue 1 June 2017 \\
CSRᄃ \\
Journal homepage: www.publishing.globalcsrc.org/jafee \\
\hline
\end{tabular}

\title{
Asset Growth and Profitability of PLCs in SAARC Economies
}

\author{
${ }^{1}$ Khawaja Khalid Mehmood \\ Assistant Professor, Institute of Management Sciences, Bahauddin Zakariya University,Multan, Pakistan. \\ khawjakhalid@bzu.edu.pk
}

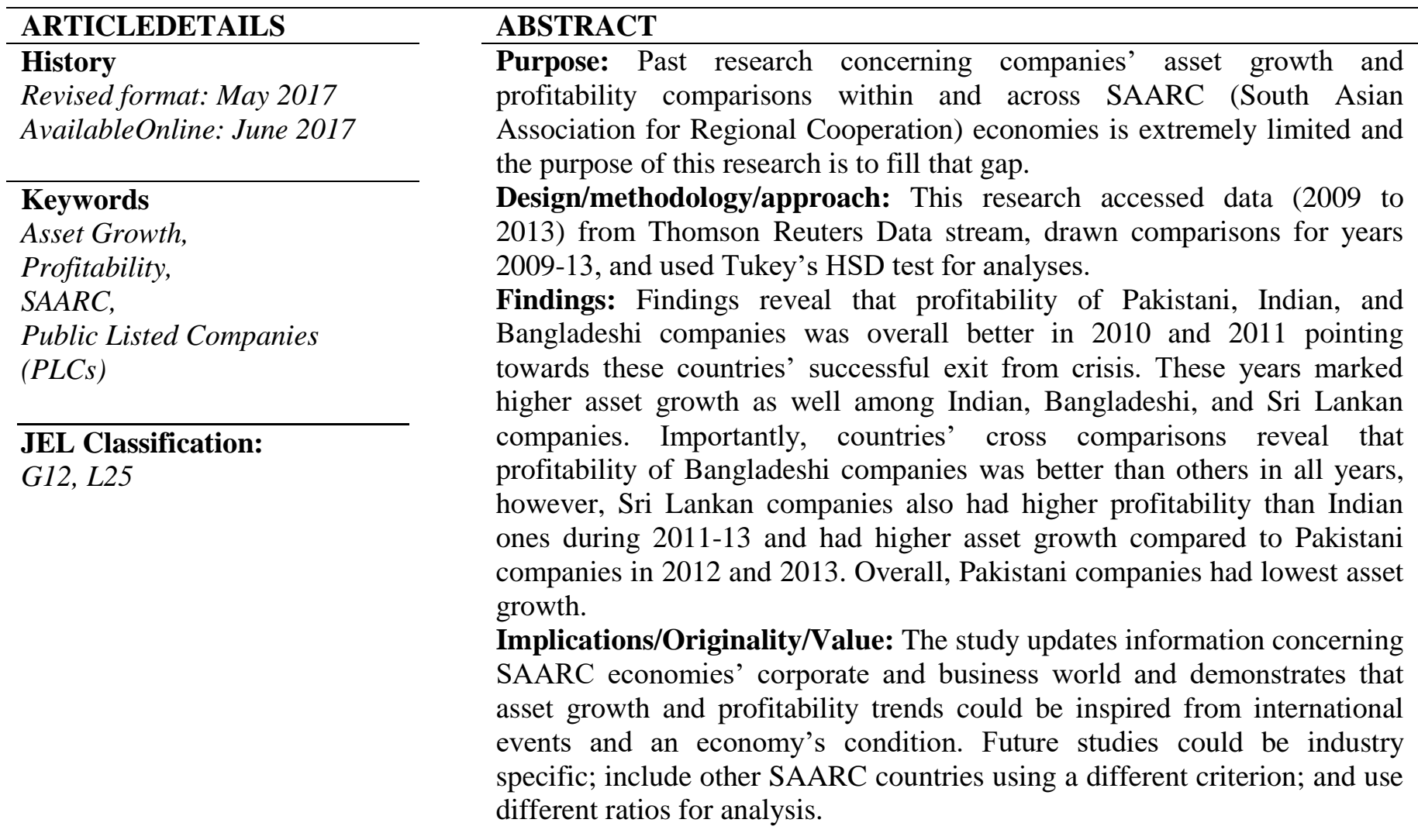

(C) 2017 The authors, under a Creative Commons AttributionNonCommercial 4.0

Corresponding author's email address: khawjakhalid@bzu.edu.pk

Recommended citation:Mehmood,K.K., (2017). Asset Growth and Profitability of PLCs in SAARC Economies.Journal of Accounting and Finance in Emerging Economies, 3(1) 33-46

DOI:https://doi.org/10.26710/jafee.v3i1.159

\section{Introduction}

Founded in 1985, SAARC has been important organization for South Asian countries; established for promoting interaction and crafting shared vision for mutual benefits (Zaman, Atif, \& Farooq, 2011). SAARC countries share number of similarities such as geographical proximity, social and agricultural backwardness, illiteracy, and poverty; yet the countries are dissimilar in their economic and trade policies (Khan, 2015). Hence, specific patterns of political stability and economic growth vary among countries as also indicated through their varying GDPs. Indisputably, corporate and banking sectors in SAARC countries need to aggressively contribute to the overall economic balance and prosperity. Effective government policies regarding key economic variables such as labor rates, investor incentives, taxes, and 
electricity and fuel prices could actually boost up these sectors; whereas ineffective policies might indeed cripple their performance.

International events and crises might as well affect these sectors significantly (Raj \& Roy, 2014). GFC severely impacted all countries including South Asian countries leaving them with difficult economic conditions and awkward corporate and banking sector performance (Kumar, 2013). Hence, monitoring companies' asset growth and profitability is important to assess business climate and it could provide crucial information for business and economic policy making (Malik, 2013). It could indeed be considered more important for SAARC countries due to inherent economic problems in them.

For SAARC economies, though numerous research exists on different subjects like renewable energy, economic growth, FDI (Alam et al., 2015; Zeb, Salar, Awan, Zaman, \&Shahbaz, 2014); stock market returns, banking income and market power (Nguyen, Skully, \&Perera, 2012; Singhania\& Prakash, 2014); trade openness, education, and investment (Tahir, Estrada, Khan, \& Afridi, 2016). But, there is less research and information regarding companies' asset growth and profitability comparisons within and across SAARC countries which represents a research gap. Whereas, comparisons of asset growth and profitability are important to perform for judging companies' diversification levels and economic prosperity with reference to global financial crises during the period. Hence, this study attempts to fill this information gap. The following sections provide review of literature, methodology, results and conclusions.

\section{Literature Review}

As indicated above, substantial studies have been conducted in different subjects for SAARC countries. Study of Zeb et al. (2014) concerning energy production, carbon emissions, GDP, and poverty indicated that poverty and GDP positively affected energy production whereas carbon emissions negatively affected it. Another similar study by Alam et al. (2015) found that financial development, per capita GDP, and FDI significantly impacted energy demand in the SAARC region. Study of Singhania and Prakash (2014) in context of stock markets behavior reported that existing stock prices depended on previous stock prices implying serial autocorrelation in stock market returns.

In banking context, study of Nguyen et al. (2012) based on four SAARC countries (Pakistan, India, Bangladesh, Sri Lanka) found that banks with higher market power put greater emphasis on conventional interest income producing activities. For same countries, in 2013, another study by Perera, Skully, and Chaudhry investigated determinants of commercial banks' profitability. However, research into companies' profitability and asset growth comparisons within and across SAARC countries has been limited. In fulfilling its objective, this study relies on companies data (2009-2013) belonging to four SAARC countries: Pakistan, India, Bangladesh, and Sri Lanka which is consistent with studies of Nguyen et al. (2012) and Perera et al. (2013). In fact, these four nations hold supreme importance in the region due to their economies (Zaheer, 2013). Table 1 below includes GDP of SAARC countries and indicates that the sample countries have been top four with respect to their GDPs over the five years period.

Table 1. SAARC Countries GDP (at market prices)

\begin{tabular}{lccccc}
\hline Countries & $\mathbf{2 0 0 9}$ & $\mathbf{2 0 1 0}$ & $\mathbf{2 0 1 1}$ & $\mathbf{2 0 1 2}$ & $\mathbf{2 0 1 3}$ \\
\hline Afghanistan & $12,486,943,506$ & $15,936,800,636$ & $17,930,239,400$ & $20,536,542,737$ & $20,458,939,155$ \\
\hline Bangladesh & $102,477,791,472$ & $115,279,077,465$ & $128,637,938,711$ & $133,355,749,482$ & $149,990,451,022$ \\
\hline Bhutan & $1,264,758,198$ & $1,585,472,534$ & $1,820,207,626$ & $1,823,692,110$ & $1,798,333,726$ \\
\hline India & $1,365,371,474,049$ & $1,708,458,876,830$ & $1,835,814,449,585$ & $1,831,781,515,472$ & $1,861,801,615,478$ \\
\hline Maldives & $2,166,330,189$ & $2,323,401,759$ & $2,449,576,518$ & $2,514,041,557$ & $2,790,659,901$ \\
\hline Nepal & $12,854,985,464$ & $16,002,656,434$ & $18,913,574,371$ & $18,851,513,891$ & $19,271,168,018$ \\
\hline Pakistan & $168,152,775,283$ & $177,406,854,515$ & $213,755,282,059$ & $224,646,134,571$ & $231,086,513,915$ \\
\hline
\end{tabular}


Source: World Bank

The following section provides brief information regarding performance of different businesses and sectors as well as overall economic outlook in recent years in sample countries.

\subsection{Economic Outlook and Business Performance in SAARC}

\subsubsection{Pakistan}

Textile, sports goods, sugar, cement and fertilizers are main industrial sectors of Pakistan. During 200910, industrial sector growth was $4.9 \%$ and its contribution to GDP was 18.5\% (Rizwan, 2015), whereas the contribution during 2013-14 increased to 20.8\% (Ministry of Finance, Government of Pakistan [MFGoP], 2014). According to MFGoP (2014) manufacturing sector was most important during 2013-14 with its $65 \%$ contribution followed by construction (11.48\%), mining and quarrying (14.45\%), and electricity and gas. Cement was claimed to be more profitable sector during 2012-13 (Bhutta\&Tirmizi, 2013).

Pakistan's average GDP growth for 2009-13 marks lowest at 3\% compared to that of India (7.48\%), Bangladesh $(5.92 \%)$, and Sri Lanka $(6.48 \%)^{1}$. Basically, economic development in Pakistan has been severely affected by ongoing terrorist threats and activities (Hyder, Akram, \&Padda, 2015). Consequently, Pakistan's corporate sector has been dwindling during previous years. But, there has been certain recovery after 2009. After Moody's announcement of conversion of five large Pakistani banks' outlook from 'negative' to 'stable', stock market flourished, resulting into KSE 100 Index passing 30000 barriers for a new record (Umar, 2014). As a result of certain government initiatives, industrial sector recorded growth of 5.8\% during 2013-14 against of 1.4\% in preceding year (MFGoP, 2014).

\subsubsection{India}

India has been among rapidly growing economies after China and had GDP growing greater than 9\% during 2008-09 (Dongre, 2012). According to World Bank source, India had highest average GDP of 7.48\% during 2009-13 among Pakistan, Bangladesh and Sri Lanka. Historically, India's economic growth stemmed majorly from its early 1990's decision to embrace regime of trade openness, free flow of resources and competitive markets. Consequently, Indian economy grew 40\% faster during two decades after 1991 (Ezell \& Atkinson, 2014). The industrial production grew by 13\% during 1995-96 and maintained consistency in other years (Dongre, 2012). But, according to Mazumdar (2014), the contribution of Indian industrial sector did not touch even $30 \%$ contrary to around $45 \%$ in other developing countries.

Investment in various sectors has been quite remarkable in India. Chittoor and Aulakh (2015) report that during 1990 there were just under 2000 companies in India which increased to around 8390 in 2010. The tremendous growth in number of companies is eventually evident through huge industrial production of Rs.899144 crores during 2007-08, however at the same time there are arguments that economic growth seemed to slow down last several years (Dongre, 2012; Ezell \& Atkinson 2014).

\subsubsection{Bangladesh}

Bangladesh is a developing country and its economic growth has stayed between $4 \%$ and $6 \%$ per year (Alam, Begum, Buysse, \& Van Huylenbroeck, 2012). In real terms, the GDP since 1971 has tripled, population growth declined to $1.4 \%$ from $2.9 \%$, whereas food production has raised three times (Belal, Cooper, \& Khan, 2015). According to the Economy Watch, the country's economy has been growing around $6 \%$ since last two decades in spite of passive implementation of economic reforms, inadequate

\footnotetext{
${ }^{1}$ http://data.worldbank.org/indicator/NY.GDP.MKTP.KD.ZG
} 
electricity supply, corruption, poor infrastructure, political instability, and global financial crisis ${ }^{2}$. The important industrial sectors include electronics, leather products, ceramics, chemicals, and pharmaceuticals (Nath, 2012). The industrial sector's contribution towards GDP has been increasing during last few years. Further, garments' exports have been significant. In 2013, these exports passed \$21billion amounting to $18 \%$ of $\mathrm{GDP}^{3}$.

\subsubsection{Sri Lanka}

With an economy of $\$ 80.591$ billion in 2015 and per capitaGDP of around $\$ 11,069$ (IMF figures ${ }^{4}$ ), $\underline{\text { Sri }}$ Lanka has been demonstrating favorable growth last few years. Though Sri Lanka is categorized among lower middle income nations, yet it offers availability of several commodities, good infrastructure, urbanization, and modernization (Maliyadde, 2013). Sri Lanka entered GFC with a fragile economic condition having double figure inflation, higher debt to GDP ratio, and higher fiscal deficit; yet it made rapid recovery owing to several variables such as huge foreign capital inflows, expansionary fiscal policy, and falling interest rates (World Bank, 2010).

Sri Lankan major industrial sectors comprise mining and manufacturing (in particular textiles and cement); whereas service sectors include tourism, banking and insurance (Kish Trade Promotion Centre [KTPC, 2002]). According toPerera and Wickremasinghe (2010), manufacturing sector contributed substantially to Sri Lanka's export income as well as national income. Also, the banking sector marked significant growth as evident through fast expansion in its total assets since 1998 (Weersainghe\&Perera, 2013).

\section{Data and Methodology}

This research needed data concerning ROIC and TAG of public listed companies operating in various sectors during 2009-2013. For the four SAARC countries, companies listed on Karachi Stock Exchange (Pakistan), National Stock Exchange (India), Dhaka Stock Exchange (Bangladesh), and Colombo Stock Exchange (Sri Lanka) were taken into the sample. All data were accessed using Thomson Reuters DataStream as this is frequently used and reliable data provider (Bohl, Diesteldorf, \&Siklos, 2015). The study incorporated companies in SAARC countries as these countries possess a lot of economic, geographical and political similarities (Khan, 2015).

\subsection{ROIC}

Among accounting based measures of profitability, ROIC has been commonly employed by previous scholars and it indicates company's payoff from investment or company's effectiveness in turning capital into profits and also shows its ability to reward suppliers of long term capital and attracting potential investors (Damodaran, 2007; Weijermars, 2012).

Following formula is used by Datastream for computing ROIC:

(Net Income-Bottom Line + ((Interest Expense on Debt-Interest Capitalized) x (1-Tax Rate)))x100/Average of Current Year's and Last Year's (Total Capital + Short Term Debt \& Current Portion of Long Term Debt)

\subsection{TAG}

Total Asset Growth has been frequently utilized accounting ratio which indicates company's investment activities and rate of change in it (Lewis \& Tan, 2016). Following formula is used by Datastream for computing TAG:

\footnotetext{
${ }^{2}$ See http://www.economywatch.com/economic-statistics/country/Bangladesh/

3 See http://www.indexmundi.com/bangladesh/economy_profile.html

${ }^{4}$ http://www.imf.org/external/pubs/ft/weo/2015/01/weodata/weorept.aspx?pr.x=48\&pr.y=18\&sy=2014\&ey=2019\&scsm=1\&ss $\mathrm{d}=1 \&$ sort=country\&ds=.\&br=1\&c=524\&s=NGDPD\%2CNGDPDPC\%2CPPPGDP\%2CPPPPC\&grp=0\&a=\#download
} 
(Total Assets (Recent Year) / Total Assets (Previous Year) - 1) x 100

As mentioned earlier, sample selection of countries was principally made on basis of their GDP growth rate as well as their data complexity. After having outliers removed through box plots (Li, Huang, Chen, \& Chang, 2014), there were 13385 observations for ROIC, and 13884 observations for TAG. SPSS was used to run the analyses and all pair wise comparisons of ratios across countries and various years were obtained by Tukey's HSD Test (Pinto, Stanislawczuk, Loguercio, Grande, \& Bauer, 2014).

\subsection{Findings}

\subsection{ROIC and TAG comparisons in SAARC}

\subsubsection{Pakistani Companies' Profitability and Asset Growth Analysis}

Table 2 shows that profitability (ROIC) of Pakistani companies almost doubled in 2011 with ROIC of $10.84 \%$ from $5.5 \%$ of 2009 and it stayed high in other consecutive years as well with 2013 having highest ROIC (11.26\%). Alternatively, Total Asset Growth (TAG) showed a decreasing trend.

Table 2: ROIC and TAG of Pakistani Companies (2009-13)

\begin{tabular}{lllll}
\hline Variable & Year & N & Mean & SD \\
\hline \multirow{4}{*}{ ROIC } & 2009 & 166 & 5.50 & 22.09 \\
& 2010 & 177 & 9.25 & 16.26 \\
& 2011 & 182 & 10.84 & 17.75 \\
& 2012 & 177 & 9.42 & 19.30 \\
& 2013 & 163 & 11.26 & 25.33 \\
& Total & $\mathbf{8 6 5}$ & $\mathbf{9 . 2 8}$ & $\mathbf{2 0 . 3 3}$ \\
\hline \multirow{4}{*}{ TAG } & 2009 & 166 & 15.38 & 58.12 \\
& 2010 & 177 & 13.62 & 26.80 \\
& 2011 & 184 & 11.73 & 18.43 \\
& 2012 & 179 & 12.51 & 17.59 \\
& 2013 & 165 & 6.87 & 21.18 \\
& Total & $\mathbf{8 7 1}$ & $\mathbf{1 2 . 0 5}$ & $\mathbf{3 1 . 8 3}$ \\
\hline
\end{tabular}

Now consider Table 3 regarding results of Tukey's HSD Test (only significant findings are discussed in whole analyses; legend for Table 3 also applies to all other tables). Table 3 affirms that profitability of Pakistani companies was significantly higher in 2013 compared to one in 2009.

Table 3: Tukey's HSD Test for Pakistani Companies

\begin{tabular}{lll}
\hline ROIC & & \\
\hline (I) Year & (J) Year & $\begin{array}{l}\text { Mean } \\
\text { Difference }(\mathbf{I}-J)\end{array}$ \\
\hline 2009 & 2010 & -3.74 \\
& 2011 & -5.34 \\
& 2012 & -3.91 \\
& 2013 & $-5.75^{*}$ \\
\hline 2010 & 2011 & -1.59 \\
& 2012 & -.17 \\
& 2013 & -2.01 \\
\hline 2011 & 2012 & 1.42 \\
& 2013 & -.41 \\
\hline 2012 & 2013 & -1.84 \\
\hline
\end{tabular}

$*($ significant at .10 level), $* *$ (significant at .05 level), *** (significant at .01 level)

\subsubsection{Indian Companies' Profitability and Asset Growth Analysis}


Table 4 indicates that ROIC of Indian companies increased in 2010 (9.72) after which it was falling consecutively (average ROIC has been $7.92 \%$ ). Table 5 also indicates that 2010 was better year compared to 2009, 2012, and 2013 regarding Indian companies' profitability. Profitability in 2011 was also higher than that in 2013. Table 4 shows that TAG was maximum in 2011 at $24.13 \%$ amongst all years. Table 5 provides substantial support for this. Additionally, it shows that 2010 also marked higher TAG compared to 2009, 2012, and 2013. Therefore, it concludes that Indian companies aggressively went for asset growth during 2010 and 2011.

Table 4: ROIC and TAG of Indian Companies (2009-13)

\begin{tabular}{lllll}
\hline Variable & Year & N & Mean & SD \\
\hline \multirow{4}{*}{ ROIC } & 2009 & 2292 & 7.50 & 21.83 \\
& 2010 & 2314 & 9.72 & 22.89 \\
& 2011 & 2232 & 8.59 & 20.09 \\
& 2012 & 2296 & 7.26 & 20.01 \\
& 2013 & 2119 & 6.41 & 21.23 \\
& Total & $\mathbf{1 1 2 5 3}$ & $\mathbf{7 . 9 2}$ & $\mathbf{2 1 . 2 7}$ \\
\hline \multirow{4}{*}{ TAG } & 2009 & 2324 & 18.03 & 43.90 \\
& 2010 & 2363 & 21.66 & 53.64 \\
& 2011 & 2355 & 24.13 & 57.83 \\
& 2012 & 2395 & 16.156 & 44.17 \\
& 2013 & 2296 & 12.48 & 37.78 \\
\hline
\end{tabular}

Table 5: Tukey's HSD Test for Indian Companies

\begin{tabular}{llllll}
\hline ROIC & & \multicolumn{5}{c}{ TAG } \\
\hline $\begin{array}{lllll}\text { (I) } \\
\text { Year }\end{array}$ & \multirow{2}{*}{ (J) Year } & $\begin{array}{l}\text { Mean } \\
\text { Difference (I-J) }\end{array}$ & (I) Year & (J) Year & $\begin{array}{l}\text { Mean } \\
\text { Difference (I-J) }\end{array}$ \\
\hline 2009 & 2010 & $-2.22^{* * *}$ & 2009 & 2010 & $-3.62^{*}$ \\
& 2011 & -1.09 & & 2011 & $-6.09^{* * *}$ \\
& 2012 & .245 & & 2012 & 1.88 \\
& 2013 & 1.09 & & 2013 & $5.55^{* * *}$ \\
\hline 2010 & 2011 & 1.13 & 2010 & 2011 & -2.47 \\
& 2012 & $2.47^{* * *}$ & & 2012 & $5.50^{* * *}$ \\
& 2013 & $3.32^{* * *}$ & & 2013 & $9.18^{* * *}$ \\
\hline 2011 & 2012 & 1.33 & 2011 & 2012 & $7.97^{* * *}$ \\
& 2013 & $2.18^{* * *}$ & & 2013 & $11.65^{* * *}$ \\
\hline 2012 & 2013 & .85 & 2012 & 2013 & $3.68^{*}$ \\
\hline
\end{tabular}

\subsubsection{Bangladeshi Companies' Profitability and Asset Growth Analysis}

Descriptive (Table 6) for Bangladeshi companies show that profitability increased in 2010 but it was reducing in consecutive years. Asset growth kept increasing after 2009 until 2011 where it reached 35.8\%, but after that it fell sharply whereby it touched $11.6 \%$ in 2013. 
Table 6: ROIC and TAG of Bangladeshi Companies (2009-13)

\begin{tabular}{lllll}
\hline Variable & Year & N & Mean & SD \\
\hline \multirow{4}{*}{ ROIC } & 2009 & 22 & 19.50 & 12.54 \\
& 2010 & 39 & 24.61 & 17.54 \\
& 2011 & 47 & 16.81 & 12.44 \\
& 2012 & 49 & 16.67 & 14.32 \\
& 2013 & 49 & 17.07 & 13.48 \\
& Total & $\mathbf{2 0 6}$ & $\mathbf{1 8 . 6 0}$ & $\mathbf{1 4 . 4 1}$ \\
\hline \multirow{4}{*}{ TAG } & 2009 & 22 & 26.69 & 29.98 \\
& 2010 & 39 & 29.71 & 24.38 \\
& 2011 & 47 & 35.80 & 44.58 \\
& 2012 & 49 & 18.28 & 18.10 \\
& 2013 & 50 & 11.60 & 11.65 \\
\hline
\end{tabular}

Tukey's test (Table 7) also indicates that 2010 was better year regarding profitability compared to 2011 and 2012. Similarly, in 2011 TAG was significantly higher than in 2012 and 2013. Also, 2010 also marked higher TAG compared to one in 2013.

Table 7: Tukey's HSD Test for Bangladeshi Companies

\begin{tabular}{llllll}
\hline ROIC & \multicolumn{5}{c}{ TAG } \\
\hline \multirow{2}{*}{ (I) Year } & (J) Year & $\begin{array}{l}\text { Mean } \\
\text { Difference } \\
\text { J) }\end{array}$ & $\begin{array}{l}\text { (I- } \\
\text { (I) }\end{array}$ & $\begin{array}{l}\text { Year } \\
\text { (J) Year }\end{array}$ & $\begin{array}{l}\text { Mean } \\
\text { Difference } \\
\text { J) }\end{array}$ \\
\hline 2009 & 2010 & -5.12 & 2009 & 2010 & -3.02 \\
& 2011 & 2.69 & & 2011 & -9.11 \\
& 2012 & 2.83 & & 2012 & 8.41 \\
& 2013 & 2.42 & & 2013 & 15.10 \\
\hline 2010 & 2011 & $7.80^{*}$ & 2010 & 2011 & -6.08 \\
& 2012 & $7.94 *$ & & 2012 & 11.43 \\
& 2013 & 7.54 & & 2013 & $18.12^{* *}$ \\
\hline 2011 & 2012 & .14 & 2011 & 2012 & $17.52^{* *}$ \\
& 2013 & -.26 & & 2013 & $24.20^{* * *}$ \\
\hline 2012 & 2013 & -.40 & 2012 & 2013 & 6.68 \\
\hline
\end{tabular}

\subsubsection{Sri Lankan Companies’ Profitability and Asset Growth Analysis}

Table 8 shows no prominent trend regarding ROIC of Sri Lankan companies. However, it is unlike TAG. Specifically, TAG has been quite low in 2009 (14.08\%) after which it gradually increased and was maximum (30.65\%) and more than double of 2009 in 2011 (refer Table 9 also). It however, started falling after 2011 and ended up at $18.06 \%$ in 2013. 
Table 8: ROIC and TAG of Sri Lankan Companies (2009-13)

\begin{tabular}{lllll}
\hline Variable & Year & N & Mean & SD \\
\hline \multirow{4}{*}{ ROIC } & 2009 & 210 & 9.26 & 21.94 \\
& 2010 & 208 & 12.05 & 16.08 \\
& 2011 & 208 & 13.68 & 20.78 \\
& 2012 & 218 & 12.61 & 20.65 \\
& 2013 & 217 & 10.51 & 18.08 \\
& Total & $\mathbf{1 0 6 1}$ & $\mathbf{1 1 . 6 2}$ & $\mathbf{1 9 . 6 5}$ \\
\hline \multirow{4}{*}{ TAG } & 2009 & 212 & 14.08 & 48.75 \\
& 2010 & 210 & 23.08 & 69.40 \\
& 2011 & 209 & 30.65 & 60.0 \\
& 2012 & 221 & 22.75 & 52.63 \\
& 2013 & 221 & 18.06 & 35.40 \\
\hline
\end{tabular}

Table 9: Tukey's HSD Test for Sri Lankan Companies

\begin{tabular}{|c|c|c|c|}
\hline \multicolumn{4}{|l|}{ TAG } \\
\hline $\begin{array}{l}\text { (I) } \\
\text { Year }\end{array}$ & (J) Year & $\begin{array}{l}\text { Mean } \\
\text { (I-J) }\end{array}$ & Difference \\
\hline \multirow[t]{4}{*}{2009} & 2010 & -9.01 & \\
\hline & 2011 & $-16.57 * *$ & \\
\hline & 2012 & -8.67 & \\
\hline & 2013 & -3.99 & \\
\hline \multirow[t]{3}{*}{2010} & 2011 & -7.56 & \\
\hline & 2012 & .33 & \\
\hline & 2013 & 5.02 & \\
\hline \multirow[t]{2}{*}{2011} & 2012 & 7.90 & \\
\hline & 2013 & 12.58 & \\
\hline 2012 & 2013 & 4.68 & \\
\hline
\end{tabular}

\subsubsection{Conclusion and Discussion}

Profitability and asset growth patterns have been distinct for different countries (refer to Figure 1 also). Regarding ROIC, Sri Lankan companies did not show any prominent pattern. For Pakistani companies, 2011 and 2013 were particularly better. In fact, GFC had adverse impact on world economies. Scholars reported that in Pakistan, it severely affected stock exchange volatility and had a negative impact on companies' profitability (Ali \& Afzal, 2012). Abbas, Tahir, Rehman, and Perviz (2012) reported lower profitability of textile based companies for instance, during the crisis. Years 2010 and 2011 were better for Indian companies regarding profitability, and 2010 have been better for Bangladeshi companies.

As regards TAG, it has been falling after 2009 for Pakistani companies. A sort of inverted U-shaped curve was reflected of TAG for Indian and Sri Lankan companies. Overall, TAG was higher in 2010 and 2011 for Indian and Bangladeshi companies. Better profitability of Indian companies during 2010 and 2011 is indicative of India's successful recovery from GFC. IMF (International Monetary Fund) report (2011) noted that 2600 Indian companies had higher profits and lesser interest obligations. Later, IMF report (2013a) mentioned substantial slowdown in India's overall growth after successful recovery. Specifically, it reported that Indian companies' profitability that recovered post GFC deteriorated afterwards mainly due to increasing interest rates, slow permits for infrastructure projects, and falling demand levels. The effects of GFC on Bangladeshi economy were somehow mixed (Akter\& Basher, 2014). Hence, Mollik and Bepari (2010) also reported that instead of GFC striking the country, stock prices on Dhaka Stock Exchange were continuously increasing. Bangladesh also seemed to show similar economic trend as of 
India after 2011 as for instance, IMF (2013b) reported higher profitability (ROA and ROE) of Bangladeshi banks in 2010 compared to that of 2011 and 2012. Higher asset growth among Sri Lankan companies during 2011 against 2009 could also be attributed to similar factors as for Indian and Bangladeshi companies.

Figure 1. Companies' TAG and ROIC (2009-2013)

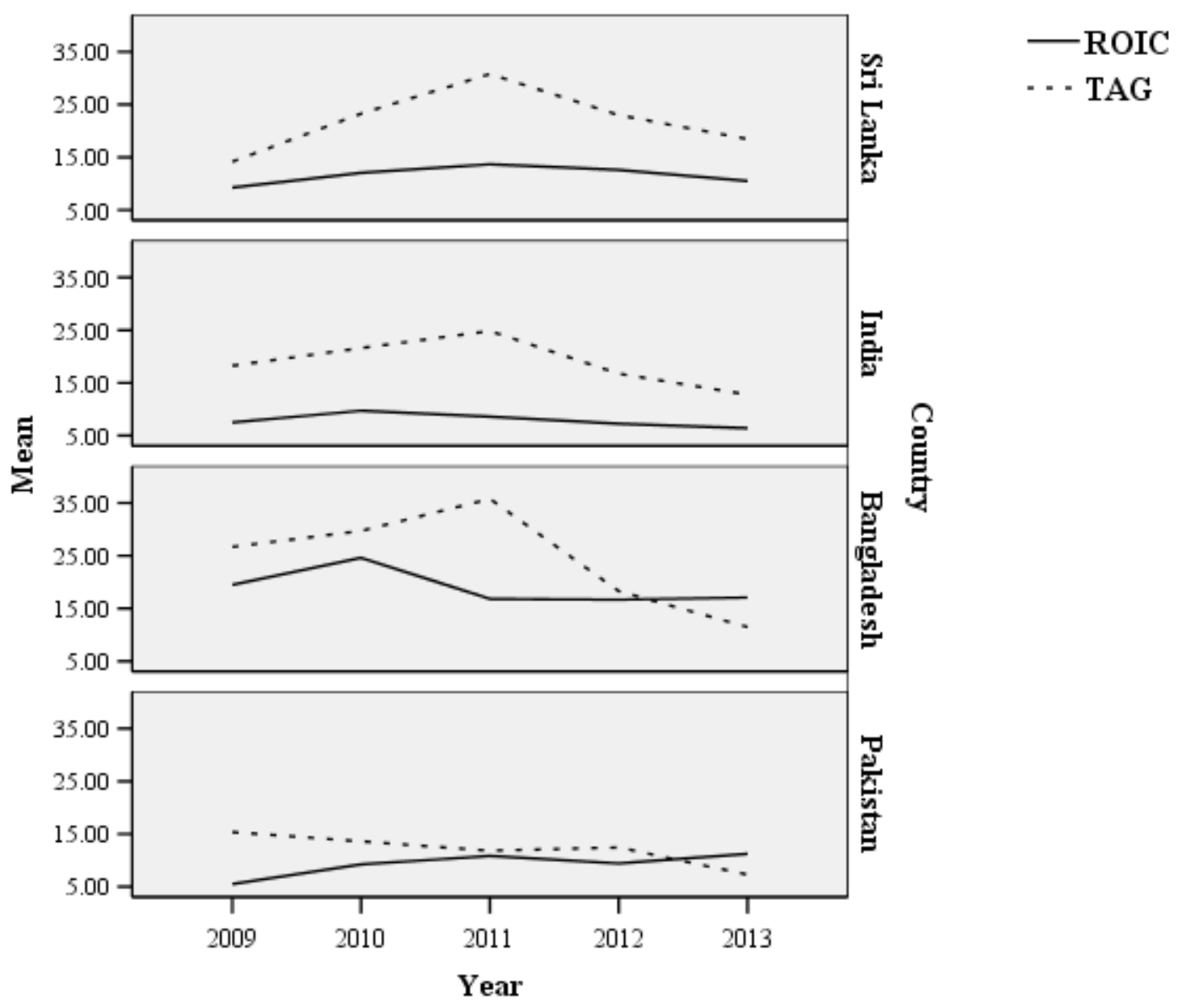

\subsection{Comparison of Companies' ROIC and TAG among SAARC Countries}

This section includes comparison of countries on ROIC and TAG during 2009-2013. Consider Table 2, 4, 6, and 8. Regarding 2009, they indicate that Bangladeshi companies had maximum ROIC (19.50\%) and TAG (26.69\%). Pakistani companies had lowest ROIC (5.5\%), whereas Sri Lankan companies had lowest TAG (14.08\%). Tukey's Test (Table 10) reveals that Bangladeshi companies did better in profitability than Pakistani and Indian companies in 2009.

Table 10. Tukey's HSD Test for 2009

\begin{tabular}{lll}
\hline ROIC & & \\
\hline (I) Year & $(\mathbf{J})$ Year & Mean Difference (I-J) \\
\hline Pakistan & Bangladesh & $-13.99 * *$ \\
& India & -1.99 \\
& Sri Lanka & -3.75 \\
\hline Bangladesh & India & $11.99 *$ \\
& Sri Lanka & 10.24 \\
\hline India & Sri Lanka & -1.75 \\
\hline
\end{tabular}


Year 2010 descriptives in Table 2, 4, 6, and 8 indicate that Bangladeshi companies again had higher ROIC (24.61\%) and TAG (29.71\%). Regarding ROIC, Pakistani and Indian companies ranked lower than others. For TAG, Sri Lankan companies were second to Bangladeshi companies, while Pakistani companies had lowest TAG (13.62\%). Table 11 verifies that Bangladeshi companies had significantly better profitability compared to all others.

Table 11. Tukey's HSD Test for 2010

\begin{tabular}{lll}
\hline ROIC & & \\
\hline (I) Year & $(\mathbf{J})$ Year & Mean Difference (I-J) \\
\hline Pakistan & Bangladesh & $-15.36^{* * * *}$ \\
& India & -.47 \\
& Sri Lanka & -2.80 \\
\hline Bangladesh & India & $14.88^{* * *}$ \\
& Sri Lanka & $12.56^{* * *}$ \\
\hline India & Sri Lanka & -2.32 \\
\hline
\end{tabular}

Descriptives for 2011 (Table 2, 4, 6, and 8) show that Bangladeshi companies had maximum ROIC (16.81\%) and TAG (35.80\%). Alternatively, Indian companies had lowest ROIC of $8.59 \%$ and Pakistani companies had lowest TAG of 11.73\%. Table 12 affirms that Bangladeshi and Sri Lankan companies were more profitable than Indian companies. Regarding TAG, it reveals that Pakistani companies had lowest TAG of all.

Table 12. Tukey's HSD Test for 2011

\begin{tabular}{|c|c|c|c|c|c|}
\hline \multicolumn{2}{|c|}{ ROIC } & \multicolumn{3}{|c|}{ TAG } & \multirow[b]{2}{*}{$\begin{array}{l}\text { Mean Difference } \\
(\mathbf{I}-\mathbf{J})\end{array}$} \\
\hline (I) Year & (J) Year & $\begin{array}{l}\text { Mean Difference } \\
(\text { I-J) }\end{array}$ & (I) Year & (J) Year & \\
\hline \multirow{2}{*}{ Pakistan } & India & 2.25 & & India & $-12.40 * *$ \\
\hline & Sri Lanka & -2.84 & & Sri Lanka & $-18.92 * * *$ \\
\hline Bangladesh & India & $8.22 * *$ & Bangladesh & India & 11.67 \\
\hline India & Sri Lanka & $-5.09 * * *$ & India & Sri Lanka & -6.52 \\
\hline
\end{tabular}

Year 2012 descriptives (Table 2, 4, 6, and 8) show that Bangladeshi companies had highest profitability (16.67\%) followed by Sri Lankan companies (12.61\%); while Indian companies had lowest (7.26\%). However, TAG of Sri Lankan companies for this year were highest among others (22.75\%). Table 13 also confirms that Bangladeshi and Sri Lankan companies were more profitable than Indian companies. On TAG, Sri Lankan companies had significantly higher TAG than Pakistani companies.

Table 13. Tukey's HSD Test for 2012

\begin{tabular}{llllll}
\hline ROIC & & TAG & \\
\hline (I) Country & $(\mathbf{J})$ Country & $\begin{array}{l}\text { Mean Difference } \\
(\mathbf{I}-J)\end{array}$ & (I) Country & (J) Country & $\begin{array}{l}\text { Mean } \\
\text { Difference (I-J) }\end{array}$ \\
\hline Pakistan & Bangladesh & -7.25 & Pakistan & Bangladesh & -5.77 \\
& India & 2.16 & & India & -3.64 \\
& Sri Lanka & -3.19 & Sri Lanka & $-10.24 *$ \\
\hline Bangladesh & India & $9.41 * * *$ & Bangladesh & India & 2.13 \\
& Sri Lanka & 4.05 & Sri Lanka & -4.47 \\
\hline India & Sri Lanka & $-5.36^{* * *}$ & India & Sri Lanka & -6.59 \\
\hline
\end{tabular}


Descriptives for 2013 (Table 2, 4, 6, and 8) show that Bangladeshi companies had highest profitability $(17.07 \%)$ followed by Pakistani companies (11.26\%); while Indian companies had lowest $(6.41 \%)$. However as for year 2012, TAG of Sri Lankan companies for 2013 had been highest among others (18.06\%). Pakistani companies had lowest TAG (6.87\%). Tukey's test (Table 14) reveals that Indian companies' profitability had been lowest of all. Sri Lankan companies had higher TAG than that of Pakistani companies.

Table 14. Tukey's HSD Test for 2013

\begin{tabular}{|c|c|c|c|c|c|}
\hline \multicolumn{2}{|c|}{ ROIC } & \multicolumn{3}{|c|}{ TAG } & \multirow[b]{2}{*}{$\begin{array}{l}\text { Mean } \\
\text { Difference (I-J) }\end{array}$} \\
\hline (I) Country & (J) Country & Difference & (I) Country & (J) Country & \\
\hline \multirow[t]{3}{*}{ Pakistan } & Bangladesh & -5.82 & Pakistan & Bangladesh & -4.73 \\
\hline & India & $4.85^{* *}$ & & India & -5.60 \\
\hline & Sri Lanka & .74 & & Sri Lanka & $-11.19 * *$ \\
\hline \multirow[t]{2}{*}{ Bangladesh } & India & $10.66^{* * *}$ & Bangladesh & India & -.88 \\
\hline & Sri Lanka & 6.56 & & Sri Lanka & -6.47 \\
\hline India & Sri Lanka & $-4.10 * *$ & India & Sri Lanka & -5.59 \\
\hline
\end{tabular}

\subsubsection{Conclusion}

As part of additional analysis, comparisons of countries on the variables were made for all years altogether. Tukey's test for all years (Table 15) also indicates that Bangladeshi companies outperformed all others regarding profitability. This was followed by Sri Lankan companies which had better profitability compared to Pakistani and Indian companies. Interestingly, it also reveals that during these five years, overall, asset growth in Pakistani companies was significantly lower than in others.

The literature supports the idea that impact of GFC on all countries was not equal (Griffith-Jones \&Ocampo, 2009). Ali and Afzal (2012) assert that GFC had a negative effect on stock returns in Indian and Pakistani stock exchanges but the effect was stronger for Indian stock market. Further Kumar (2013) argues that post crisis performance of Bangladesh and Sri Lanka, for instance, was better as they continued to grow, whereas a slowdown in Indian economic growth was observed alternatively. This phenomenon might as well have triggered the differences among profitability and asset growth patterns among the four SAARC countries.

Table 15. Tukey's HSD Test for All Years

\begin{tabular}{|c|c|c|c|c|c|}
\hline \multicolumn{3}{|l|}{ ROIC } & \multicolumn{3}{|l|}{ TAG } \\
\hline (I) Country & (J) Country & $\begin{array}{l}\text { Mean I } \\
(\mathbf{I}-J)\end{array}$ & (I) Country & (J) Country & $\begin{array}{l}\text { Mean } \\
\text { Difference (I-J) }\end{array}$ \\
\hline \multirow{2}{*}{ Pakistan } & India & 1.36 & & India & $-6.47 * * *$ \\
\hline & Sri Lanka & $-2.34^{*}$ & & Sri Lanka & $-9.62 * * *$ \\
\hline Bangladesh & India & $10.68 * * *$ & Bangladesh & India & 5.18 \\
\hline India & Sri Lanka & $-3.70 * * *$ & India & Sri Lanka & -3.16 \\
\hline
\end{tabular}

\section{Limitations and Future Research}

This research accomplished its objective of comparing profitability and asset growth within and across four SAARC countries. However, future studies could include other SAARC countries using a different criterion, use different ratios for analysis, and control certain variables accounting for differences among countries. Future researchers could be industry specific as well in order to specialize the information.

\section{References}

Abbas, F., Tahir, M., Rehman, M.U., \&Perviz, A. (2012).Impact of financial crisis on textile industry in 
Pakistan.Information Management and Business Review, 4(7), 409.

Akter, S., \& Basher, S.A. (2014). The impacts of food price and income shocks on household food security and economic well-being: Evidence from rural Bangladesh. Global Environmental Change, 25, 150-162. http://dx.doi.org/10.1016/j.gloenvcha.2014.02.003

Alam, M.J., Begum, I.A., Buysse, J., \& Van Huylenbroeck, G. (2012). Energy consumption, carbon emissions and economic growth nexus in Bangladesh: Cointegration and dynamic causality analysis. Energy Policy, 45, 217-225. http://dx.doi.org/10.1016/j.enpol.2012.02.022

Alam, A., Malik, I.A., Abdullah, A.B., Hassan, A., Faridullah, Awan, U. et al. (2015). Does financial development contribute to SAARC' S energy demand? From energy crisis to energy reforms.Renewable and Sustainable Energy Reviews, 41, 818-829. http://dx.doi.org/10.1016/j.rser.2014.08.071

Ali, R., \& Afzal, M. (2012). Impact of global financial crisis on stock markets: Evidence from Pakistan and India. E3 Journal of Business Management and Economics, 3(7), 275-282.

Belal, A.R., Cooper, S.M., \& Khan, N.A. (2015). Corporate environmental responsibility and accountability: What chance in vulnerable Bangladesh? Critical Perspectives on Accounting, 33, 44-58. http://dx.doi.org/10.1016/j.cpa.2015.01.005

Bhutta, Z., \&Tirmizi, F. (2013, May 21). Can't get enough: Soaring profits not enough for cement industry. The Express Tribune. Retrieved from http://tribune.com.pk/story/552042/cant-getenough-soaring-profits-not-enough-for-cement-industry/

Bohl, M.T., Diesteldorf, J., \&Siklos, P.L. (2015). The effect of index futures trading on volatility: Three markets for Chinese stocks. China Economic Review, 34, 207-224. http://dx.doi.org/10.1016/j.chieco.2014.11.005

Chittoor, R.R., \&Aulakh, P.S. (2015). Organizational landscape in India: Historical development, multiplicity of forms and implications for practice and research. Long Range Planning, 48(5), 291-300.http://dx.doi.org/10.1016/j.lrp.2015.07.005

Damodaran, A. (2007). Return on capital (ROC), return on invested capital (ROIC) and return on equity (ROE): Measurement and implications. Retrieved from http://www.stern.nyu.edu/ adamodar/pdfiles/papers/returnmeasures.pdf.

Dongre, A.P. (2012). Policy changes in the wake of globalization and its impact on Indian industries. Journal of Policy Modeling, 34(3), 476-496. http://dx.doi.org/10.1016/j.jpolmod.2011.10.004

Ezell, S., \& Atkinson, R. (2014).The Indian Economy at a Crossroads. Washington: ITIF.

Griffith-Jones, S., \&Ocampo, J.A. (2009). The financial crisis and its impact on developing countries.United Nations Development Programme Working Paper (January, 2009). NY: UNDP.

Hyder, S., Akram, N., \&Padda, I.U.H. (2015).Impact of terrorism on economic development in Pakistan. Pakistan Business Review, January, 704-722.

International Monetary Fund (2011).India: Staff report for the 2010 Article IV consultation (Report No. 11/50). Washington: IMF.

International Monetary Fund (2013a).India: Staff report for the 2013 Article IV consultation (Report No. 13/37). Washington: IMF.

International Monetary Fund (2013b).Bangladesh: Staff report for the 2013 Article IV consultation (Report No. 13/357). Washington: IMF.

Khan, A.R. (2015).Impediments to the success of SAARC.A Research Journal of South Asian Studies, 30(1), 291-302.

Kish Trade Promotion Center (2002).Sri Lanka. Retrieved from http://www.kishtpc.com/global_serilank.htm (on 22/2/2016)

Kumar, N. (2013, January-February). Global financial crisis and south Asian economies: Outlook, risks and policy options. Presentation at the South Centre Conference, January 31 to February 1, Geneva.Retrieved http://www.southcentre.int/wpcontent/uploads/2013/08/Ev_130201_NKumar.pdf

Lewis, C.M., \& Tan, Y. (2016).Debt-equity choices, R\&D investment and market timing.Journal of Financial Economics, 1-12. http://dx.doi.org/10.1016/j.jPneco.2016.01.017 
Li, D.C., Huang, W.T., Chen, C.C., \& Chang, C.J. (2014). Employing box plots to build high-dimensional manufacturing models for new products in TFT-LCD plants. Neurocomputing, 142, 73-85. http://dx.doi.org/10.1016/j.neucom.2014.03.043

Malik, Q.A. (2013). Accounting based measures as determinants of corporate performance valuation.(Unpublished $\mathrm{PhD}$ Dissertation). Foundation University, Pakistan.

Maliyadde, C. (2013, February 24). Sri Lanka's economy after 65 years.Business Times. Retrieved from http://www.sundaytimes.lk/130224/business-times/sri-lankas-economy-after-65-years-33731.html

Mazumdar, S. (2014). India's economy: Some reflections on its shaky future. Futures, 56, 22-29. http://dx.doi.org/10.1016/j.futures.2013.10.005

Ministry of Finance, Government of Pakistan (2014).Pakistan Economic Survey 2013-14. Islamabad: MFGoP.

Mollik, A.T., \&Bepari, M.K. (2010).Instability of stock beta in Dhaka Stock Exchange, Bangladesh.Managerial Finance, 36(10), 886-902. http://dx.doi.org/10.1108/03074351011070251

Nath, N.C. (2012, July). Manufacturing sector of Bangladesh-growth, structure and strategies for future development.Paper presentation at the Biennial Conference "Global Economy and Vision 2021", July 12-14, Dhaka.

Nguyen, M., Skully, M., \&Perera, S. (2012). Market power, revenue diversification and bank stability: Evidence from selected South Asian countries. Journal of International Financial Markets, Institutions and Money, 22(4), 897-912. http://dx.doi.org/10.1016/j.intfin.2012.05.008

Perera, S., Skully, M., \& Chaudhry, Z. (2013). Determinants of commercial bank profitability: South Asian evidence. Asian Journal of Finance \& Accounting, 5(1), 365-380. http://dx.doi.org/10.5296/ajfa.v5i1.301

Perera, K.W., \&Wickremasinghe, G.B. (2010). Working capital management practices of manufacturing sector companies in Sri Lanka: Survey evidence. Investment Management and Financial Innovations, 7(4), 34-38.

Pinto, K.T., Stanislawczuk, R., Loguercio, A.D., Grande, R.H.M., \& Bauer, J. (2014).Effect of exposure time of zinc oxide eugenol restoration on microtensile bond strength of adhesives to dentin. Revista Portuguesa de Estomatologia, MedicinaDentária e CirurgiaMaxilofacial, 55(2), 83-88. http://dx.doi.org/10.1016/j.rpemd.2014.03.002

Raj, S.J.J.F., \& Roy, S. (2014). Impact of financial crisis in Asia.Procedia-Social and Behavioral Sciences, 133, 336 - 345. http://dx.doi.org/10.1016/j.sbspro.2014.04.199

Rizwan (2015).Importance of industrial sector in economic development.(Web post). Retrieved from http://www.learningall.com/importance-of-industrial-sector-in-economic-development/

Singhania, M., \& Prakash S. (2014). Volatility and cross correlations of stock markets in SAARC nations.South Asian Journal of Global Business Research, 3(2), 154-169. http://dx.doi.org/10.1108/SAJGBR-04-2012-0056

Tahir, M., Estrada, M.R., Khan, I., \& Afridi, M.A. (2016). The role of trade openness for industrial sector development: Panel data evidence from SAARC region. Journal of Asia Business Studies, 10(1), 93-103. http://dx.doi.org/10.1108/JABS-01-2015-0007

Umar, B. (2014, July 20). Weekly review: KSE-100 crosses 30,000 points to hit all-time high. The Express Tribune. Retrieved from http://tribune.com.pk/story/738030/weekly-review-kse-100crosses-30000-points-to-hit-all-time-high/

Weersainghe, V.E.I.W., \&Perera, T.R. (2013).Determinents of profitability of commercial banks in Sri Lanka.International Journal of Arts and Commerce, 2(10), 141-170.

Weijermars, R. (2012). Regulatory reform options to revitalize the US natural gas value chain. Utilities Policy, 21, 50-58. http://dx.doi.org/10.1016/j.jup.2011.12.003

World Bank (2010).Sri Lanka Economic Update. Washington: World Bank.

Zaheer, R. (2013). The economic performance of SAARC member countries.Research on Humanities and Social Sciences, 3(5), 201-2014.

Zaman, Q., Atif, M., \& Farooq, M. (2011). Standard of education and economic conditions are the main causes of the failure of SAARC: A comparative study of SAARC and EU. Interdisciplinary Journal of Research in Business, 1(3), 15-22. 
Zeb, R., Salar, L., Awan, U., Zaman, K., \&Shahbaz, M. (2014). Causal links between renewable energy, environmental degradation and economic growth in selected SAARC countries: Progress towards green economy. Renewable Energy, 71, 123-132. http://dx.doi.org/10.1016/j.renene.2014.05.012 